\title{
Design, Optimization and Analysis of a 4-stroke Diesel Engine Piston and Piston rings using Different Materials
}

\author{
Adhir Tandon* \\ 1.* Head Department of Mechanical Engineering, School of Management Sciences, Lucknow, (U.P.), India. e-mail : adhirtandon@gmail.com
}

\section{Publication Info}

Article history :

Received : $13^{\text {th }}$ May, 2018

Accepted : $25^{\text {th }}$ May, 2018

DOI : 10.18090/samriddhi.v.10i01.10

Keywords :

Piston, Aluminium Alloy-4032,

CATIA V5, Finite Element Analysis,

Steady State Thermal, ANSYS

*Corresponding author :

Adhir Tandon

e-mail : adhirtandon@gmail.com

\begin{abstract}
Modern Automobiles expect a high performance from its engines, which in turn places its requirements on the piston and cylinder components. Hence the piston has to deal with harsher, and tougher thermal and mechanical conditions. It has to undergo higher operating temperatures and pressures as well as higher speeds and at the same time keeping a check on the emissions. Pistons play a key role in increasing engine efficiency by reducing weight and frictional losses. This has made it essential to devise and search unique and creative concepts and materials for Pistons repeatedly, which offers what the engine demands. In this work Aluminium Alloy-4032 has been selected as the piston material of a 4-Stroke Diesel Engine and the piston rings are made of grey cast iron and alloy steel. Piston is designed by analytical methods taking both thermal and structural effects into consideration, then modelled on CATIA V5 and the analysis of structural deformation due to thermal stresses has been done using Finite Element Analysis of Steady State Thermal and its effect on static structure using Analysis software ANSYS.
\end{abstract}

\section{INTRODUCTION}

$\mathrm{P}$ iston is a component present in an Internal Combustion Engine or for that matter in reciprocating engines, reciprocating pumps, gas compressors and other similar mechanisms. It has a reciprocating motion, generally moving up and down in case of vertical cylinders (i.e. from TDC to $\mathrm{BDC}$ ) or left to right in case of horizontal cylinders (i.e. from IDC to ODC). It is enclosed in a cylinder, known as Engine Cylinder. The portion above the piston head is called the Combustion Chamber where the combustion of the Air-Fuel mixture takes place. The length it travels in each stroke inside the cylinder is called the Stroke Length and the volume it occupies is called the Swept Volume.

Pistons are one of the most complex yet important component amongst all other industrial components. The engine is the heart of an automobile and the piston can be considered the most important part of an engine. Numerous researches have been done in this field in the past, modifications with respect to geometries or dimensions, materials and manufacturing techniques, have been done, which has led to a continuous improvement over the years. Still there is always a scope for further improvements and modifications. The parameters can always be optimized according to the everchanging needs and requirements of the customer.

\section{LITERATURE REVIEW}

Modern Diesel Engines require injection pressures of up to 2000 bar, brake mean effective pressures of up to 200 bar, peak pressures soaring up to 205 bar and specific outputs of $100 \mathrm{~W} / \mathrm{L}$. So the Piston should be rigid and strong enough to withstand these hard conditions, hence the material 
selection for the piston is another important task in designing. Various researches in the past have shown the benefits of using Aluminum Alloy as the piston material. So, in this work a comparative study has been done through finite element analysis regarding the suitability of the type Aluminum Alloy pertaining to the conditions imposed on it, in this work. For comparison the first material selected was Aluminium Alloy-4032 as the piston material for this analysis due to its higher thermal conductivity than Cast Iron, which is around three times that of Cast Iron, hence will have a lesser temperature variation from the piston crown to the piston rings. Also its density being one-third of Cast Iron's, results in the piston being light in weight and having reduced inertia forces. The material it was compared with, in this study was yet another widely used material for Pistons of 2000 series of Aluminium Alloys, was Aluminium Alloy-2618. If we see the results of this work we will observe that Aluminium Alloy2618(refer to Table 1.1) also stood the chance but it was experimentally found in this project that Aluminium Alloy-4032 had better stress (equivalent von mises) and thermal distribution at the piston head and near the rings and the piston boss which was the aim of the analysis, and also since it is less dense than $\mathrm{Al}$ Alloy-2618 hence lighter in weight. However Al Alloy-2618 can also be an option, if a little denser and heavier piston is desired. Also, since the piston is designed keeping in mind its application in highly rated engines i.e. with piston speeds above $6 \mathrm{~m} / \mathrm{s}$, Aluminium Alloy-4032 is the best fit, due to the above mentioned advantages, which is validated from this work.

The high thermal conductivity of the aluminium alloy and the Piston ribs provide a good distribution of Von Mises stresses and thermal stresses from the piston head to the piston skirt, being highest at the piston head and lowest at the skirt. This has ensured the grooves being safe with a Factor of Safety above 2.
This project also involves the analysis of the effects of thermally induced structural stresses on the Piston Rings hence, the Rings are also designed analytically and the material is selected. First based on the past researches and present practical usage and they were then validated through Finite Element Analysis software ANSYS. Analysis results with all the 5 rings of Cast Iron showed that the first 3 (compression rings) with high deformation and a Factor of Safety below 1 and the last two safe with FOS above 1. This called for further research on the material of compression rings. Alloy Steel though costly, but had properties complementing those required of a Piston Ring appeared a suitable replacement. So the first 3 rings were now made of Alloy Steel and again analysed. This time the $4^{\text {th }}$ ring failed under stress and showed lower values of FOS. So the $4^{\text {th }}$ ring which was of Grey Cast Iron was also replaced with Alloy Steel and the again analysed. This time all the rings were safe with FOS above 2.

So, this work deals with the Design, Optimization and Analysis of the Piston and Piston Rings of a 4-Stroke Diesel Engine. The optimization of this project restricts to the materials and not the dimension or geometry, which could also be a topic for further research.

\section{DESIGN METHODOLOGY}

- Design of Piston based on analytical methods, pertaining to 4-stroke Diesel engines.

- Design of Piston Rings based on analytical methods.

- Modelling the 3D view of the Designed Piston and Rings through the 3-D modelling software CATIA V5 R17, and assembling the rings on the piston groove.

- Selection of appropriate Piston and Ring material based on the conditions they face, through various study materials, research papers, past researches and results and their practical usage. 
- First importing the 3D Modelled view of Piston through CATIA to ANSYS, the FEA Analysis software.

- Validating the selected material for the piston i.e. whether it bears the applied stresses and then comparing its behaviour with another alternatively used piston material, through Steady State Analysis and the developed mechanical stresses from it, with the help of software, hence optimizing the output of the Piston.

- Next, importing the assembly of the piston and rings to ANSYS and assigning the validated piston material and the selected ring material for observing the complete response of the assembly, which also validates the credibility of the selected ring material.

- If the ring is safe then analysis is complete, if ring fails then a research is conducted again for finding the appropriate ring material which is strong enough to bear the applied thermal stresses and the developed mechanical stresses.

- This experimental research concludes with the results suggesting the use of dimensions and materials for Piston and Rings under given thermal stresses for optimized productivity of the Piston.

Table-1: Specifications of the Designed Piston and Piston Ring

\begin{tabular}{|l|l|}
\hline Thickness of Piston Head on Strength basis & $10.206 \mathrm{~mm}$ \\
\hline Thickness of Piston Head on Heat Dissipation Basis & $14.15 \mathrm{~mm}$ \\
\hline Thickness of Ribs & $4.716 \mathrm{~mm}$ \\
\hline No. of Ribs & 4 \\
\hline Thickness of Grooves & $2.3688 \mathrm{~mm}$ \\
\hline Depth of Grooves & $3.384 \mathrm{~mm}$ \\
\hline No. of Grooves & 5 \\
\hline Requirement of Cup & Not required \\
\hline Length of Top Land & $16.98 \mathrm{~mm}$ \\
\hline Length of Ring Section & $19.42416 \mathrm{~mm}$ \\
\hline Length of the Piston Skirt & $78.54 \mathrm{~mm}$ \\
\hline Total Length of Piston & $114.47 \mathrm{~mm}$ \\
\hline Thickness of Piston Barrel at top end & $11.284 \mathrm{~mm}$ \\
\hline Thickness of Piston Barrel at lower end & $3.9494 \mathrm{~mm}$ \\
\hline Radial width of Ring & $3.384 \mathrm{~mm}$ \\
\hline Axial thickness of ring & $2.3688 \mathrm{~mm}$ \\
\hline No. of Rings & 5 \\
\hline Gap between rings (before assembly) & $11.844 \mathrm{~mm}$ \\
\hline Gap Between Rings(after assembly) & $0.2 \mathrm{~mm}$ \\
\hline
\end{tabular}

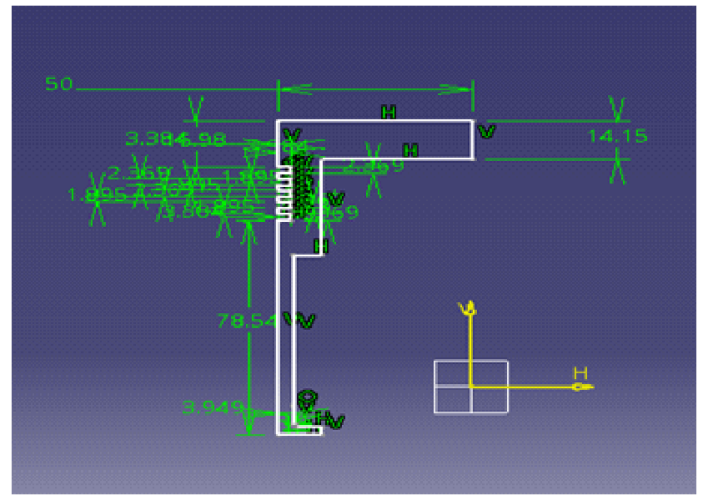

Fig.1: : 2D Sketch of the Designed Piston

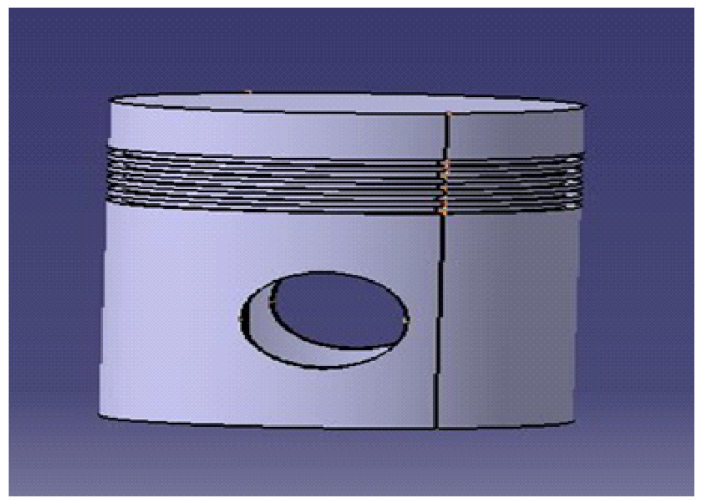

Fig.2: 3D Model of the Designed Piston

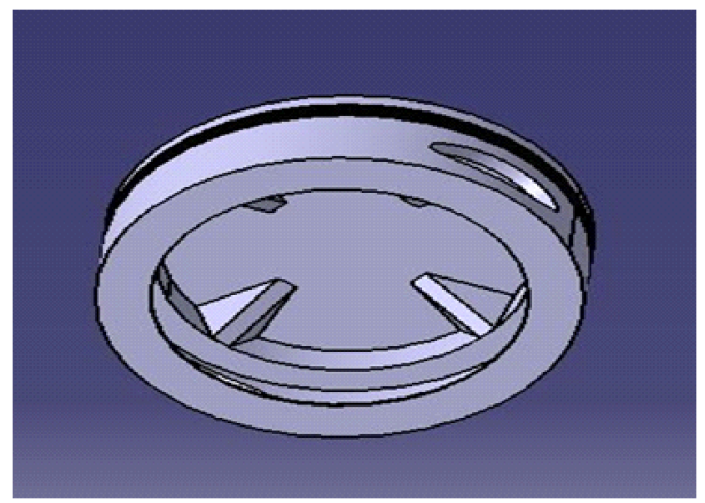

Fig.3: Bottom View of the Piston Showing Ribs

The figures above show the various views of the Piston, from 2D sketch to 3D modelling. It also shows us the presence of Piston Ribs, which are necessary for strengthening the piston head and providing rigidity at the same time transmitting thermal and mechanical stresses and temperature to the piston rings. 


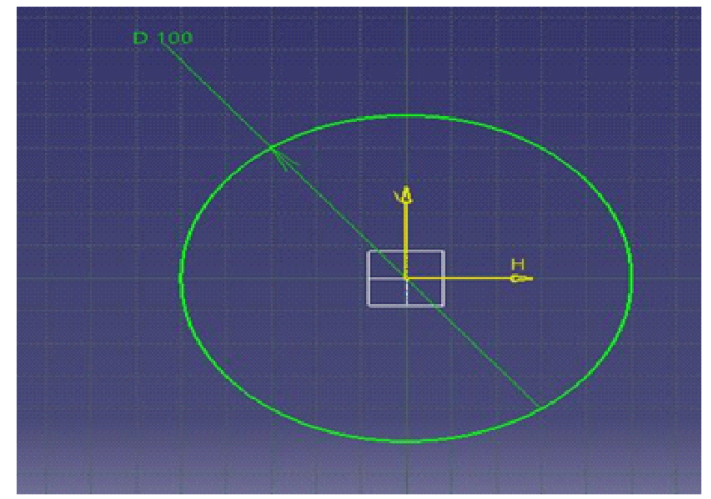

Fig.4: 2D Sketch of the Designed Piston Ring

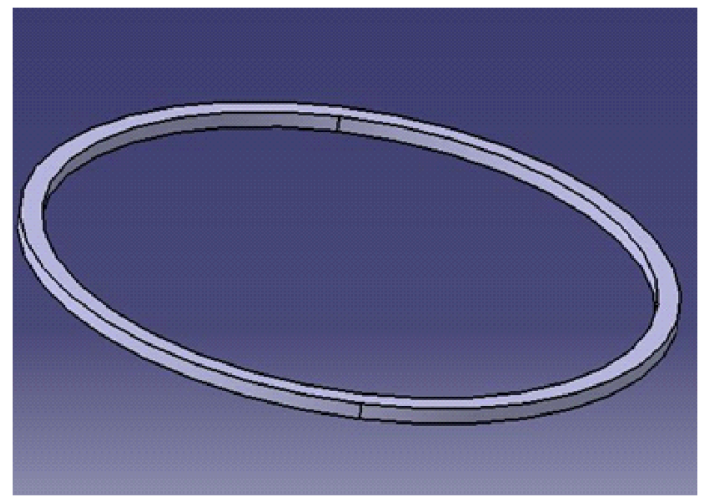

Fig.5: 3D Model of the Designed Piston Ring

The figures above show the 2D Sketch view of the Designed Piston Ring and the 3D Model of the Piston Ring, with the diameter of the ring equal to the diameter of the piston $(100 \mathrm{~mm})$. Axial thickness (h) of the Ring is $2.3688 \mathrm{~mm}$ and the Radial width of the ring is $3.384 \mathrm{~mm}$, analytical calculations of which are mentioned before.

\section{FINITE ELEMENT ANALYSIS OF PISTON}

\subsection{About the Analysis Software- ANSYS}

ANSYS, Inc. is an American Computer-aided engineering software developer headquartered south of Pittisburgh in Cecil Township, Pennsylvania, United States. ANSYS publishes engineering software across a range of disciplines including Finite Element Analysis, Structural Analysis, Computational Fluid Dynamics, Explicit and implicit methods, and heat transfer.
ANSYS Mechanical is finite element analysis tool for structural analysis, including linear, nonlinear and dynamic studies. This computer simulation product provides finite elements to model behaviour, and supports material models and equation solvers for a wide range of mechanical design problems. ANSYS Mechanical also includes thermal analysis and coupled-physics capabilities involving acoustics, piezoelectric, thermalstructural and thermos-electric analysis.

\subsection{Finite element analysis using ANSYS}

The finite element analysis of the Piston was completed in following steps:

- The designed piston is imported in ANSYS from CATIA software.

- Generation of default Mesh.

- From geometry Piston is assigned the materials Aluminium Alloy-2618.

- Steady State Thermal Analysis is then performed on it, with $650{ }^{\circ} \mathrm{C}$ (since the temperature inside the cylinder reaches to $500-600^{\circ} \mathrm{C}$ in Diesel Engines and hence a max limit of temperature was selected to compare the performance of the materials at this temperature) as the temperature applied on the Piston Head and Stagnant Water (Simplified Case) Convection at $22^{\circ} \mathrm{C}$ is applied on all the faces of the Piston except on the Piston Head.

- Temperature distribution and Total Heat Flux are estimated in the results.

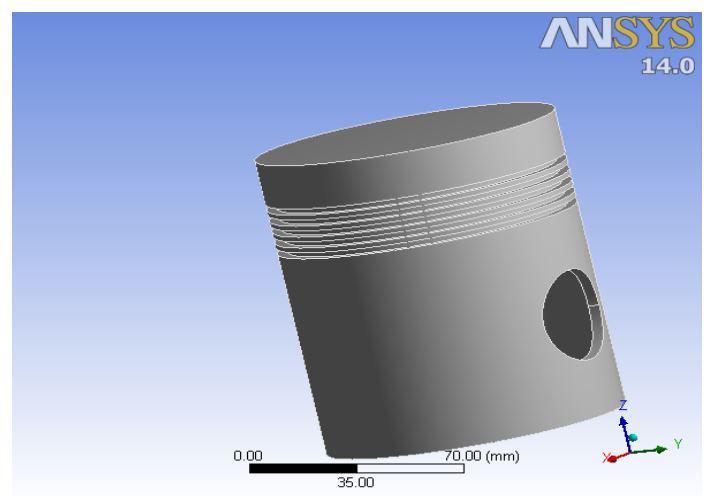

Fig.6: 3D Model of Piston imported in ANSYS 


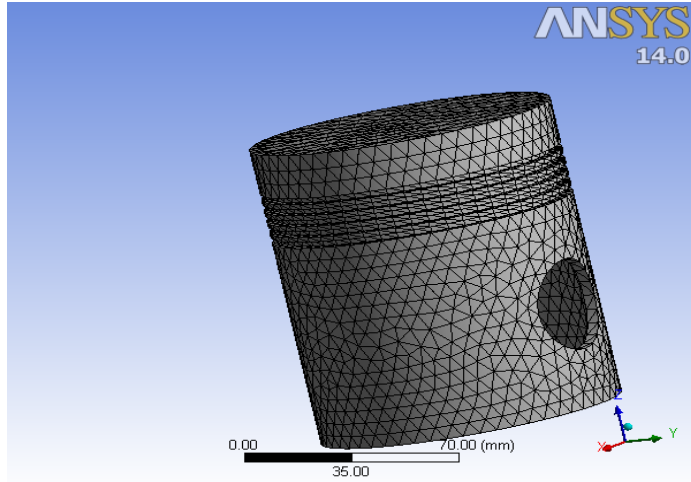

Fig.7: Mesh generation of 3D Model

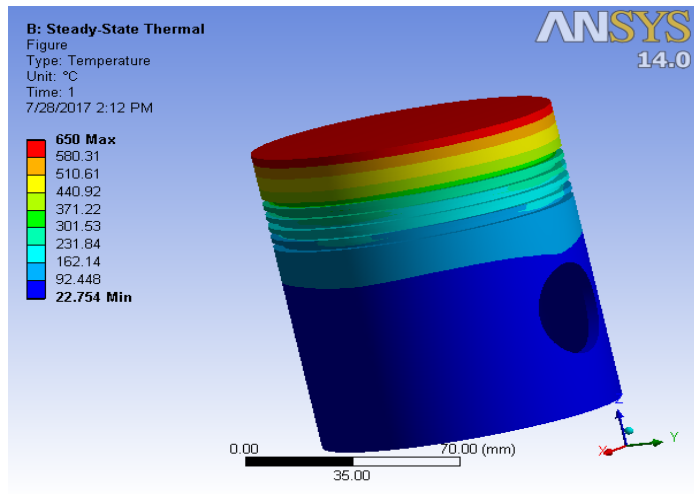

Fig.8: Temperature Distribution in Al Alloy-4032

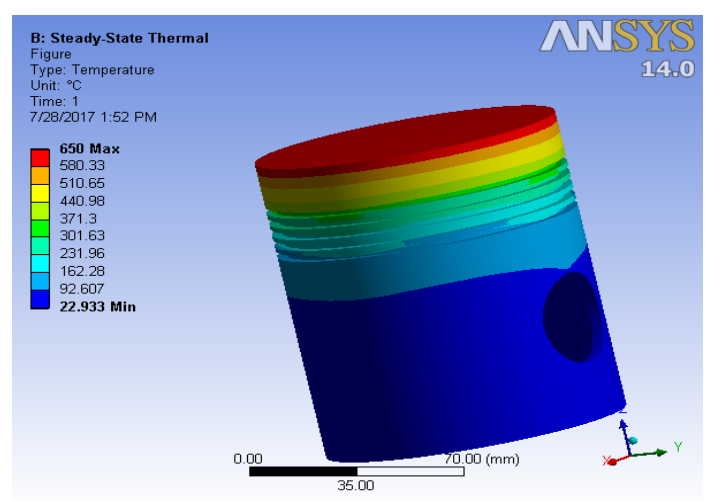

Fig.9: Temperature Distribution in Al Alloy-2618

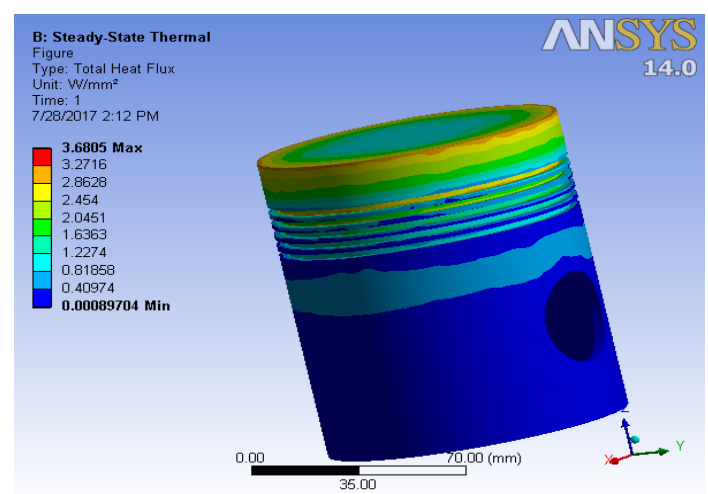

Fig.10: Total Heat Flux in Al Alloy-4032

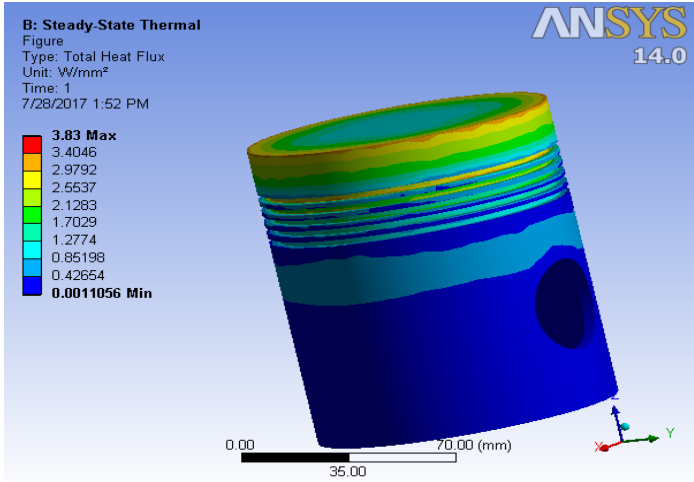

Fig.11: Total Heat Flux in Al Alloy-2618

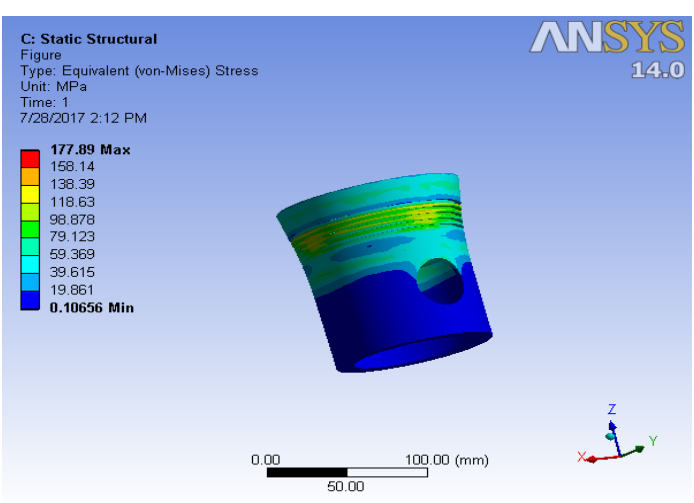

Fig.12: Von Mises Stress in Al Alloy-4032

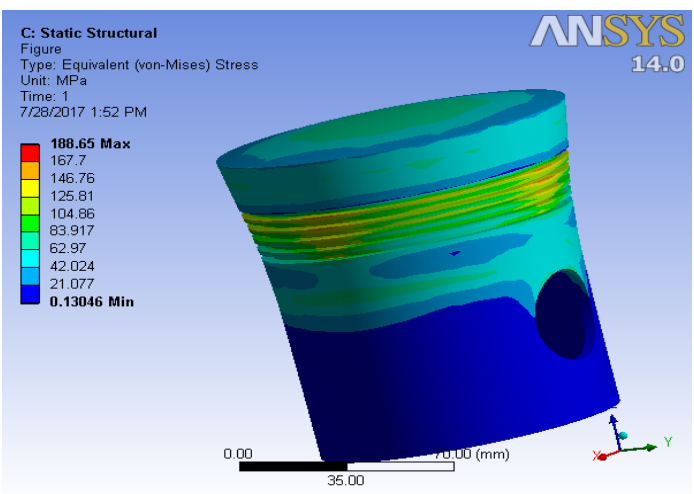

Fig.13: Von Mises Stress in Al Alloy-2618

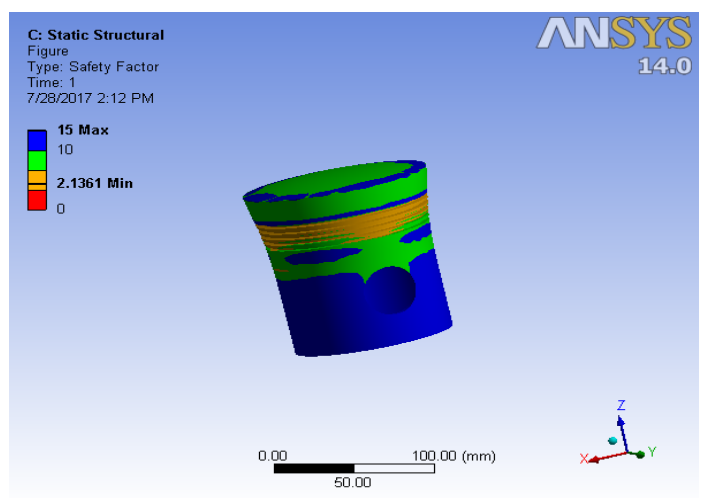

Fig.14: Safety Factor of Al Alloy-4032 


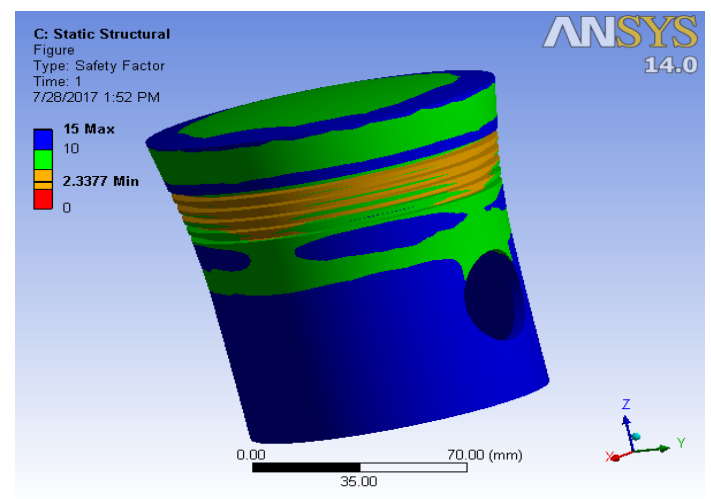

Fig.15: Safety Factor of Al Alloy-2618

Table-2: Comparison between Physical Properties of Aluminium Alloy 4032 and Aluminium Alloy 2618

\begin{tabular}{|c|c|}
\hline $\begin{array}{l}\text { ALUMINIUM ALLOY 4032 } \\
(\mathrm{Al}-(81.1-87.2 \%), \mathrm{Si}-(11-13.5 \%), \\
\text { others- } \mathrm{Mg}, \mathrm{Ni}, \mathrm{Zn}, \mathrm{Cr}, \mathrm{Fe}, \mathrm{Cu}) \\
\text { High Silicon content }\end{array}$ & $\begin{array}{l}\text { ALUMINIUM ALLOY } 2618 \\
(\mathrm{Al}-(92.4-94.9), \mathrm{Si}-(0.1- \\
0.25 \%), \text { others-Mg, Cu, } \mathrm{Zn}, \mathrm{Ni}, \mathrm{Ti}) \\
\text { Low silicon content }\end{array}$ \\
\hline Harder & Softer \\
\hline Low expansion & High expansion \\
\hline $\begin{array}{l}\text { Lower clearance between piston } \\
\text { and cylinder is needed }\end{array}$ & $\begin{array}{l}\text { Higher clearance between piston } \\
\text { and cylinder is needed }\end{array}$ \\
\hline Quieter operation & Noisier operation \\
\hline $\begin{array}{l}\text { Lower Ductility } \\
\text { Longer Life Cycle }\end{array}$ & $\begin{array}{l}\text { Higher Ductility } \\
\text { Shorter Life Cycle }\end{array}$ \\
\hline More stable and consistent & Less stable and consistent \\
\hline
\end{tabular}

Table-3: Comparison between Mechanical Thermal and Properties of Al Alloy-4032 and Al Alloy-2618

\begin{tabular}{|l|c|c|}
\hline $\begin{array}{c}\text { THERMAL AND } \\
\text { MECHANICAL } \\
\text { PROPERTIES }\end{array}$ & $\begin{array}{c}\text { ALUMINIUM } \\
\text { ALLOY-4032 }\end{array}$ & $\begin{array}{c}\text { ALUMINIUM } \\
\text { ALLOY-2618 }\end{array}$ \\
\hline Elastic Modulus & $79000 \mathrm{~N} / \mathrm{mm}^{2}$ & $74500 \mathrm{~N} / \mathrm{mm}^{2}$ \\
\hline Poisson's Ratio & 0.34 & 0.33 \\
\hline Shear Modulus & $26000 \mathrm{~N} / \mathrm{mm}^{2}$ & $28008 \mathrm{~N} / \mathrm{mm}^{2}$ \\
\hline Mass Density & $2680 \mathrm{~kg} / \mathrm{m}^{3}$ & $2760 \mathrm{~kg} / \mathrm{m}^{3}$ \\
\hline Tensile Strength & $380 \mathrm{~N} / \mathrm{mm}^{2}$ & $441 \mathrm{~N} / \mathrm{mm}^{2}$ \\
\hline Yield Strength & $315 \mathrm{~N} / \mathrm{mm}^{2}$ & $372 \mathrm{~N} / \mathrm{mm}^{2}$ \\
\hline $\begin{array}{l}\text { Thermal Exp. } \\
\text { Coefficient }\end{array}$ & $1.94 \mathrm{e}-005 / \mathrm{K}$ & $2.2 \mathrm{e}-005 / \mathrm{K}$ \\
\hline Thermal Conductivity & $138 \mathrm{~W} /(\mathrm{m} \mathrm{K})$ & $160 \mathrm{~W} /(\mathrm{mK})$ \\
\hline Specific Heat & $850 \mathrm{~J} /(\mathrm{kg} \mathrm{K})$ & $880 \mathrm{~J} /(\mathrm{kgK})$ \\
\hline Reference Temperature & $22{ }^{0} \mathrm{C}$ & $22{ }^{0} \mathrm{C}$ \\
\hline
\end{tabular}

Table-4: Comparison of Parameters of Analysis for $\mathrm{Al}$ Alloy-4032 and Al Alloy-2618.

\begin{tabular}{|l|c|c|}
\hline \multicolumn{1}{|c|}{ PARAMETERS } & $\begin{array}{c}\text { AL ALLOY- } \\
\mathbf{4 0 3 2}\end{array}$ & $\begin{array}{c}\text { AL ALLOY- } \\
\mathbf{2 6 1 8}\end{array}$ \\
\hline $\begin{array}{c}\text { Temperature } \\
\text { Distribution(Min. Temp) }\end{array}$ & $22.754^{{ }^{0} \mathrm{C}}$ & $22.93^{{ }^{0} \mathrm{C}}$ \\
\hline Total Heat Flux & $3.6805 \mathrm{~W} / \mathrm{mm}^{2}$ & $3.83 \mathrm{~W} / \mathrm{mm}^{2}$ \\
\hline Max Von Mises Stress & $177.89 \mathrm{~N} / \mathrm{mm}^{2}$ & $188.65 \mathrm{~N} / \mathrm{mm}^{2}$ \\
\hline Total Deformation & $0.71738 \mathrm{~mm}$ & $0.8092 \mathrm{~mm}$ \\
\hline Factor Of Safety & 2.1361 & 2.33 \\
\hline
\end{tabular}

After the Finite Element Analysis of the two pistons, we can observe that both the Piston materials are safe for the applied thermal loads (Factor Safety greater than 2) and have more or less similar thermal characteristics (Total Heat Flux and Temperature Distribution). However, the Von Mises stresses developed in the Al Alloy-2618 are greater than $10 \mathrm{MPa}$ than in Al Alloy-4032 and the deformation in the former is also greater. Hence for more optimized results we have selected Al Alloy-4032 as the Piston material.

\section{FINITE ELEMENT ANALYSIS OF PISTON ASSEMBLY}

After validating the Piston material, the next task is to validate the proposed Ring material. So, the Piston and Ring assembled in CATIA modelling software is imported in the ANSYS software, for further analysis. After the geometry is imported we generate the mesh of the model in ANSYS for Finite Element Analysis. To make the analysis more precise the relevance of the mesh has been increased to 100 . Rest all the other parameters has been taken of default mesh.

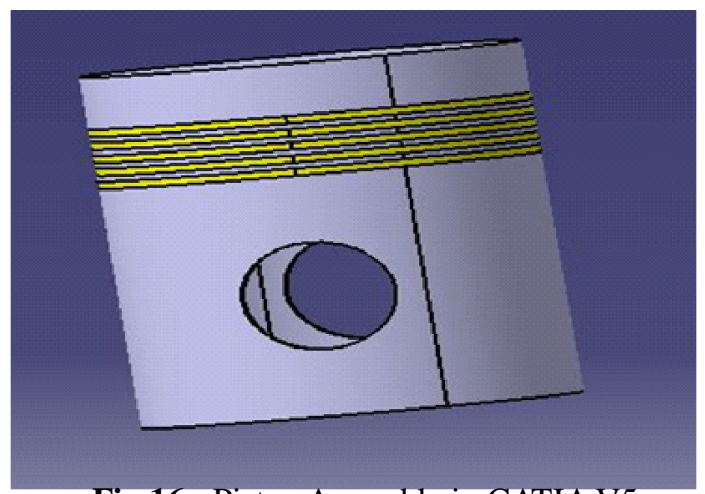

Fig.16 : Piston Assembly in CATIA V5

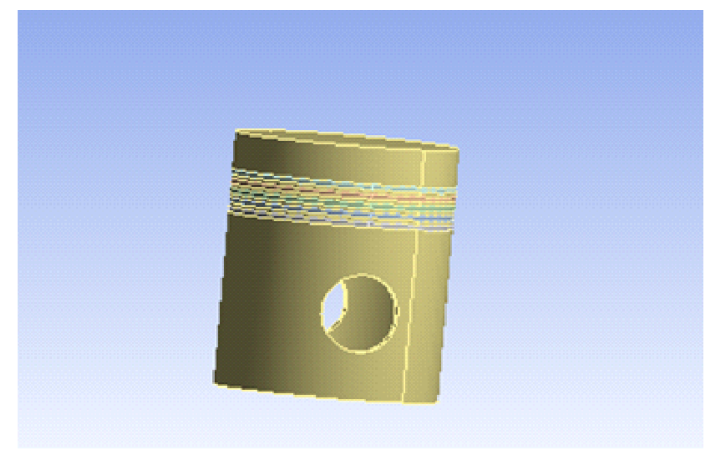

Fig.17: Piston Assembly imported in ANSYS 


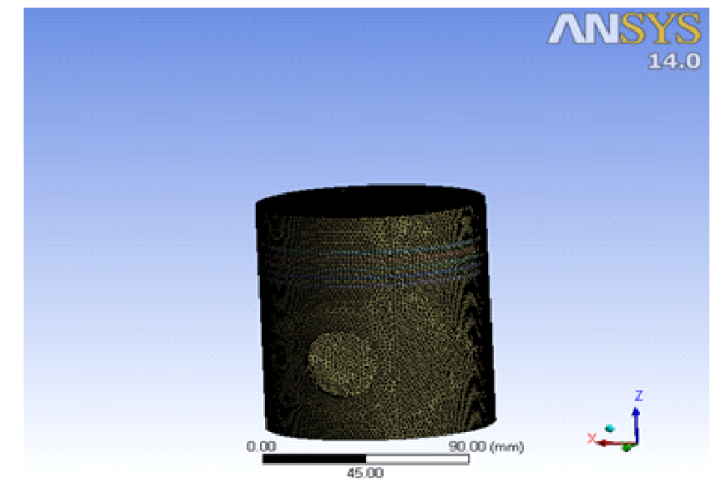

Fig.18: Assembly Mesh generation in ANSYS

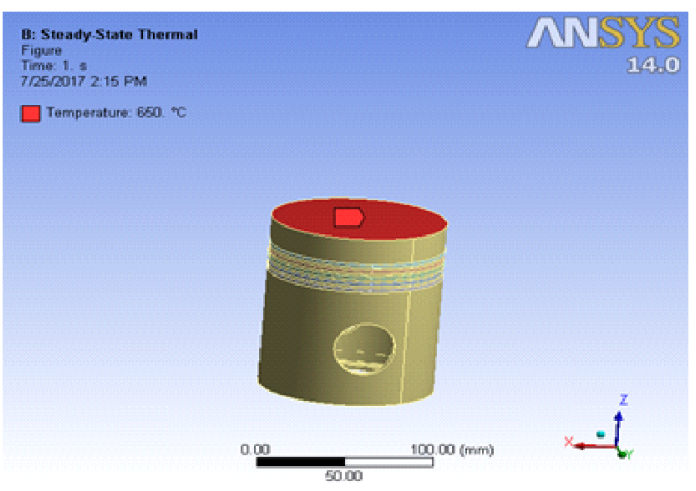

Fig.19: Application of Temperature on Head

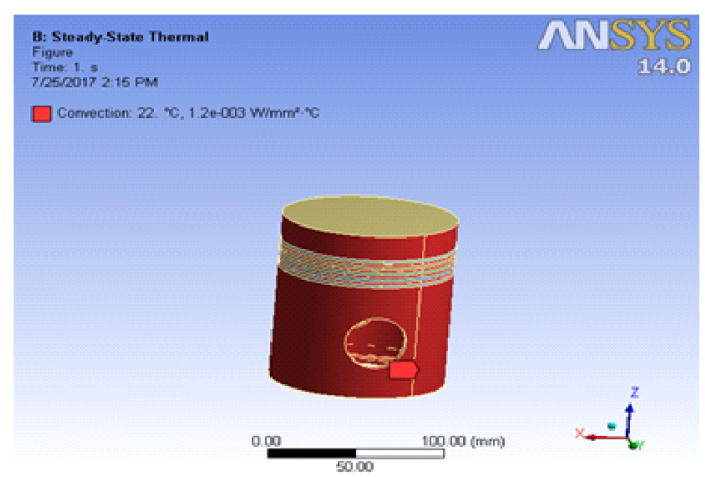

Fig.20: Convection on the surfaces and rings at

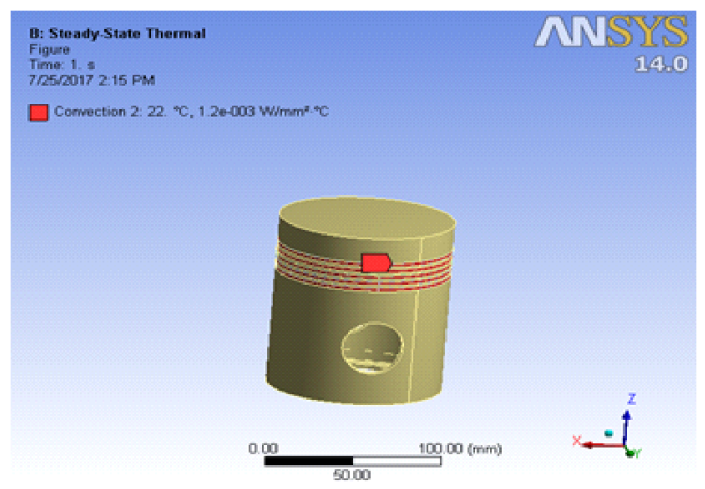

Fig.21: Convection at the grooves $\left(22^{\circ} \mathrm{C}\right)$

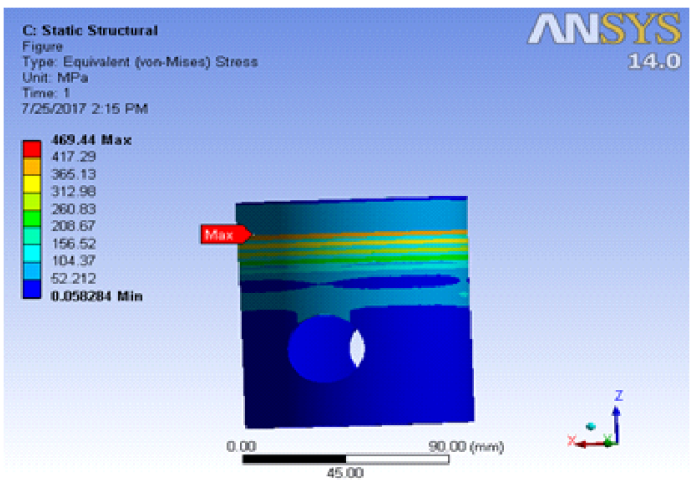

Fig.22: Von Mises Stress distribution for assembly

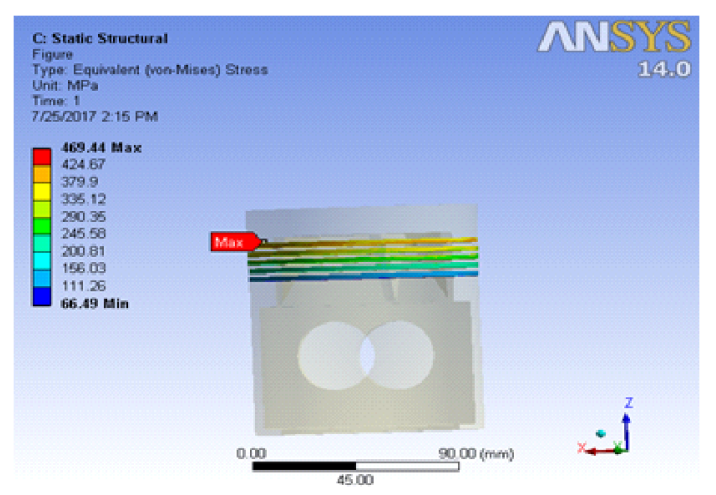

Fig.23: Von Mises Stress distribution for rings

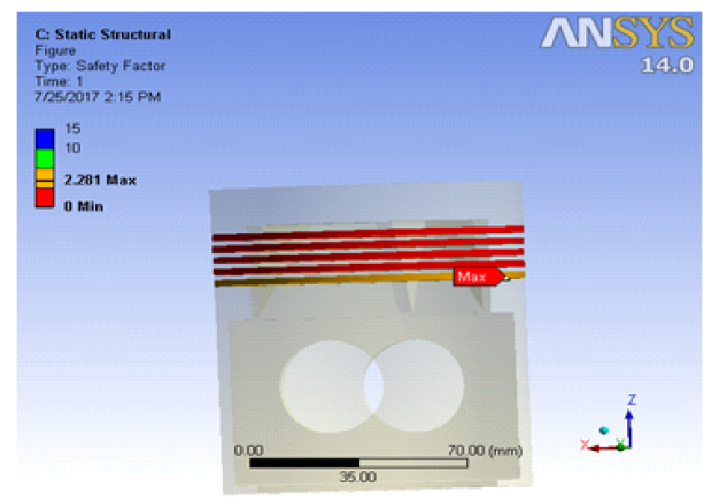

Fig.24: Factor Safety of Piston Rings (All of Grey C.I.)

The Factor of Safety of Piston Rings computed by Finite Element Analysis shows that under the given thermal stress and induced mechanical stress, the first 4 rings ( 3 compression and 1 oil scraper ring) fails, (see fig 32) yielding a Factor of Safety of 0 , while the last oil ring is safe with a Factor of Safety of 2.281.

A solution to this was found by researching about other metals and alloys that are strong 
enough to bear the applied thermal and mechanical loads. Alloy steel was then selected due to its following properties which caters to the required needs. It was then validated through Finite Element Analysis using ANSYS.

- Alloy steels have higher Strength and Hardness

- They possess high hardenability, which has great significance in heat treatment.

- Alloy steel retain their temperatures even at elevated temperatures.

- Alloy steel have a high resistance to corrosion and oxidation.

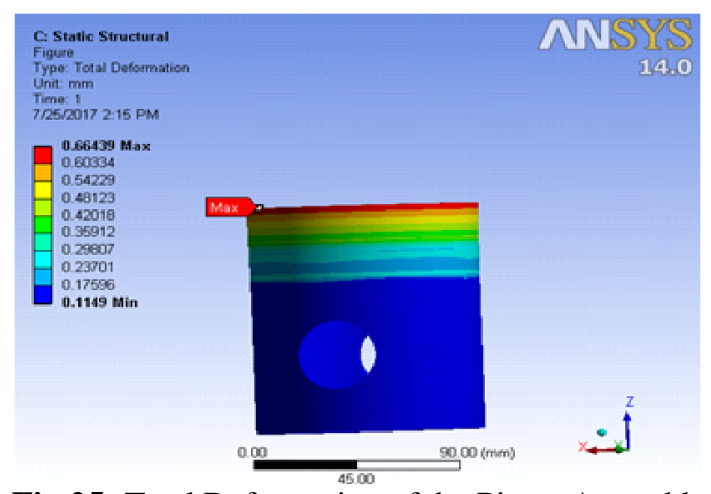

Fig.25: Total Deformation of the Piston Assembly

The maximum total deformation of the piston head has reduced in assembly as compared to the maximum deformation in piston (Al Alloy-4032) alone, which shows the benefits and efficacy of rings.

Table-5: Mechanical and Thermal Properties of Alloy Steel and Grey Cast Iron

\begin{tabular}{|l|c|c|}
\hline PROPERTIES & ALLOY STEEL & GREY CAST IRON \\
\hline ELASTIC MODULUS & $210000 \mathrm{~N} / \mathrm{mm}^{2}$ & $66178.1 \mathrm{~N} / \mathrm{mm}^{2}$ \\
POISSON'S RATIO & 0.28 & 0.27 \\
\hline MASS DENSITY & $7700 \mathrm{~kg} / \mathrm{m}^{3}$ & $7200 \mathrm{~kg} / \mathrm{m}^{3}$ \\
TENSILE STRENGTH & $723.83 \mathrm{~N} / \mathrm{mm}^{2}$ & $151.66 \mathrm{~N} / \mathrm{mm}^{2}$ \\
\hline COMPRESSIVE & $620 \mathrm{~N} / \mathrm{mm}^{2}$ & $572.17 \mathrm{~N} / \mathrm{mm}^{2}$ \\
STRENGTH & & \\
\hline THERMAL & $1.3 \mathrm{e}-005 / \mathrm{K}$ & $1.2 \mathrm{E}-005 / \mathrm{K}$ \\
EXPANSION COEFF. & & \\
\hline THERMAL & $50 \mathrm{~W} /(\mathrm{m}-\mathrm{K})$ & $45 \mathrm{~W} /(\mathrm{m}-\mathrm{K})$ \\
CONDUCTIVITY & & \\
\hline SPECIFIC HEAT & $460 \mathrm{~J} /(\mathrm{kg}-\mathrm{K})$ & $510 \mathrm{~J} /(\mathrm{kg}-\mathrm{K})$ \\
\hline
\end{tabular}

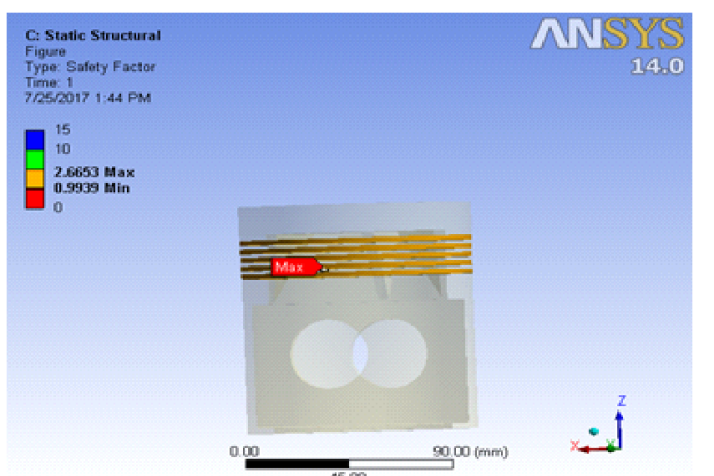

Fig.26: Factor Safety of Piston Rings (4 Alloy Steel, Grey C.I.)

The first 4 grey cast iron rings which yielded a Factor of Safety of 0 were replaced by the Alloy Steel rings, while the last ring was still taken of Grey Cast Iron. They were then reanalysed through the software. After the reanalysis, results showed that all the rings were safe and the Factor of Safety of the rings increased to 2.66 into the safe zone. (Fig 34).

\section{CONCLUSION}

Hence, the goal of the project was achieved, i.e. optimizing the results by using different materials through analysis on a designed Piston Ring assembly. Optimization of the results can be done either by varying the geometrical parameters or thermal conditions or by varying the type of material. In this project, designing, selection of materials after study and observations, and validation through Finite Element Analysis has been done until an optimized result is achieved. The thermal conditions have been kept constant throughout so that a comparison between the behaviour of different materials can be made with ease. This has helped, in deriving the conclusion that under the above imposed thermal stresses and conditions and the mechanical stresses generated with it, a better choice of the piston material will be Al Alloy-4032 instead of Al Alloy-2618, and a choice of Piston Rings made of Alloy steel should be made instead of Grey Cast Iron. 


\section{SCOPE FOR FURTHER RESEARCH}

This analysis has employed the exact values which were computed theoretically through formulas, like the thickness of Piston Head, Max Gas Pressure, thickness of Rib, Piston Ring dimensions etc. Results can be modified by varying these parameters and the materials used according to the focus of research. Alloy steel Piston rings can be replaced by a material having same properties and function, thus reducing the cost. Another scope for research will be finding an, efficacious, feasible and cost effective coating for grey cast rings.

\section{REFERENCES}

[1] Design and Structural Analysis of IC Engine Piston Using FEA Method by S.Sathishkumar, Dr.,M.Kannan, S.Arunkumar, S.Rajeshkumar, A.Muruganandam.

[2] Ramjee and K. Vijaya Kumar Reddy, "Performance analysis of a 4-stroke SI engine using CNG as an alternative fuel", Indian Journal of Science and Technology, Vol. 4, No. 7, July 2011.

[3] MirosáawWendeker, PaweáMagryta, Adam Majczak,MichaáBiaáy, "ModellingThe Thermal Loads in the Subaru EJ25 Engine" Journal of KONES Powertrain and Transport, Vol. 18, No. 1, pp. 683-688, 2011.

[4] Comparison of Forged wrought Aluminium Alloy4032 and 2618 by MAHLE.

[5] Linear Static Structural Analysis Of Optimized Piston For Bio-Fuel Using ANSYS International Journal of Mechanical and Production Engineering Research and Development (IJMPERD) ISSN 2249-
6890 Vol. 3, Issue 2, Jun 2013, 11-20 @ TIPRC Pvt. Ltd. By Ch.VenkataRajam, P. V. K. Murthy, M. V. S. Murali Krishna.

[7] Design Analysis and Optimization of Piston using CATIA and ANSYS - International Journal of Innovative Research inSimulation of ThermalMechanical Strength for Marine Engine Piston Using FEA Journal of Engineering Research and Applications www.ijera.com ISSN : 2248-9622, Vol. 4, Issue 3( Version 1), by Elijah MusangoMunyao, Jiang GuoHe, YangZhiyuan, Zou Xiang Yi .

[7] Piston Strength Analysis Using FEM- Swati S Chougule, Vinayak H Khatawat / International Journal of EngineeringResearch and Applications (IJERA) ISSN: 2248-9622 www.ijera.com Vol. 3, Issue 2, March -April 2013, pp.1724-1731 by Swati S Chougule, Vinayak H Khatawate.

[8] Design a four-cylinder Internal Combustion Engine International Journal of Mechanical Engineering Research andApplications Vol. 1 Issue 5, October 2013 .ISSN: 2347-1719by Radoslav Plamenov Georgiev, Dr. Pedro VillanuevaRoldan Dk.

[9] Design, Analysis and Optimization of Three Aluminium Piston Alloys Using FEAAjay Raj Singh et al Int. Journal ofEngineering Research and Applications www.ijera.com ISSN : 2248-9622, Vol. 4, Issue 1( Version 3, January 2014,pp.94-102 by Ajay Raj Singh, Dr.Pushpendra Kumar Sharma.

[10] Http://www.makeitfrom.com/material-properties/ 2618-2618-T61-3.1924-Aluminum

[11] Http://www.makeitfrom.com/material-properties/ 4032-4032-T6-alsi12.5mgcuni-Aluminum

[12] Design of Machine Elements by VB Bhandari 
